\title{
Use of GTEM-cell and Wire Patch Cell in calculating thermal and non-thermal biological effects of electromagnetic fields
}

\author{
Marija Salovarda Lozo and Kresimir Malaric \\ Faculty of Electrical Engineering and Computing, Zagreb \\ Croatia
}

\section{Introduction}

The increasing use of technology in our everyday environment has led to the ubiquitous presence of electromagnetic fields. These leeds to many new researches in past ten years which deal with biological effects of high frequency fields, especialy GSM frequency band. For that purposse developed are appropiate exposure systems.

In 1996, the World Health Organization (WHO) established the guidelines for quality Electromagnetic field experiments, where the importance of well-defined and characterised exposure conditions was emphasised.

Various system designs have been used for the exposure. Most of them belong to one of the following basic design ideas: Transverzal Electromagnetic (TEM) cell, RF chambers, radial transmission lines (RTL), waveguides or Wire Patch Cells (WPC).

In this chapter focus would be on G-TEM cell and Wire Patch Cell, their construction, characteristics, usage, advantages and disadvantages.

Performed were several models and tests with different power output levels in order to see field distribution inside system. As most of biological effects caused by RF electromagnetic radiation are thermal, temperature distribution and increase were also noted in order to separate temperature rise because of exposure system itself and temperature rise due to electromagnetic field levels.

\section{Biological effect of Electromagnetic fields}

Exposure to electromagnetic fields is not a new phenomenon. However, due to the increasing use of technology in our everyday environment has led to the ubiquitous presence of electromagnetic fields. Such fields arise wherever there is a voltage or a current. All types of radio broadcasting and TV transmitters produce electromagnetic fields, and they also arise in industry, business and the home, where they affect us even if our sense organs perceive nothing. Everyone is exposed to a complex mix of weak electric and magnetic fields, both at home and at work. 
Generally we can divide biological effects of electromagnetic radiation on non-thermal end thermal effects. Non-thermal biological effects are related to low frequency electromagnetic field and are mostly manifested as induced currents in human body. Thermal biological effects occur due to hifg frequency electromagnetic fields. Radio frequency radiation interacts with matter by causing molecules to oscillate with the electric field. This interaction is most effective for molecules that are polar (have their own internal electric field) such as water. The water molecule loses this rotational energy via friction with other molecules and causes an increase in temperature. This effect is the basis for microwave cooking (Michelson et al, 1987).

Temperature increase during exposure to high frequency electromagnetic waves depends on: the specific area of the body exposed and the efficiency of heat elimination; intensity of field strength; duration of exposure; specific frequency or wavelength; and thickness of skin and subcutaneous tissue. Each frequency in the electromagnetic spectrum is absorbed by living tissue at a different rate, called the specific absorption rate or SAR, which has units of watts per kilogram $(\mathrm{W} / \mathrm{kg})$. Related to human thermoregulation, organs with the least blood flow are most endangered. The eyes are particularly vulnerable to RF energy in the microwave range, and prolonged exposure to microwaves can lead to cataracts.

The levels of radiofrequency fields to which people are normally exposed are very much lower than those needed to produce significant heating. The heating effect of radiowaves forms the underlying basis for current guidelines. Scientists are also investigating the possibility that effects below the threshold level for body heating occur as a result of longterm exposure.

The IEEE and many national governments have established safety limits for exposure to various frequencies of electromagnetic energy based on SAR.

$$
S A R=\frac{\sigma E^{2}}{\rho}
$$

Where $\mathrm{E}$ is RMS value of the electric field strength in the $\mathrm{V} / \mathrm{m}, \mathrm{\sigma}$ is the conductivity of body tissue in $\mathrm{S} / \mathrm{m}$ and $\rho$ is density of body tissue in $\mathrm{Kg} / \mathrm{m}^{3}$

In the area of biological effects and medical applications of non-ionizing radiation approximately 25,000 articles have been published over the past 30 years. However, some gaps in knowledge about biological effects exist and need further research (WHO).

\subsection{Regulation and standards}

When the problem of electromagnetic pollution became evident, government and many non-governmental organizations came to solution to this problem with limitation of field strength. Over the years this limitations are getting stricter as measurements results showed growing number of new radiation sources. Individual countries have different approaches to the limits stipulated in the various regulations, standards, norms and recommendations.

In Table 1. Are exposure EMF limits by international organizations:

ICNIRP (International Commission on Non-ionizing Radiation Protection), IEEE (Institute of electrical and electronics engineering), CENELEC (European Committee for Electrotechnical Standardization). 


\begin{tabular}{|l|l|l|l|l|}
\hline Frequency & & FCC occup. & ICNIRP occup. & $\begin{array}{l}\text { DIV V EXPO- } \\
\text { Range 2 }\end{array}$ \\
\hline $50 / 60 \mathrm{~Hz}$ & Power delivery & --- & $\begin{array}{l}500 \mu \mathrm{T} \\
(B \text {-Field })\end{array}$ & $\begin{array}{l}1.251 \mu \mathrm{T} \\
(B \text {-Field })\end{array}$ \\
\hline $27 \mathrm{MHz}$ & $\begin{array}{l}\mathrm{CB} \text { radio, } \\
\text { diathermy }\end{array}$ & $68.2 \mathrm{~V} / \mathrm{m}$ & $61.0 \mathrm{~V} / \mathrm{m}$ & $61.4 \mathrm{~V} / \mathrm{m}$ \\
\hline $100 \mathrm{MHz}$ & FM radio & $61.4 \mathrm{~V} / \mathrm{m}$ & $61.4 \mathrm{~V} / \mathrm{m}$ & $61.4 \mathrm{~V} / \mathrm{m}$ \\
\hline $433 \mathrm{MHz}$ & $\begin{array}{l}\text { Industrial } \\
\text { applications }\end{array}$ & $73.4 \mathrm{~V} / \mathrm{m}$ & $62.4 \mathrm{~V} / \mathrm{m}$ & $62.4 \mathrm{~V} / \mathrm{m}$ \\
\hline $900 \mathrm{MHz}$ & Cell, pager & $106 \mathrm{~V} / \mathrm{m}$ & $90.0 \mathrm{~V} / \mathrm{m}$ & $90.0 \mathrm{~V} / \mathrm{m}$ \\
\hline $2.45 \mathrm{GHz}$ & $\begin{array}{l}\text { Microwave, } \\
\text { industry }\end{array}$ & $137 \mathrm{~V} / \mathrm{m}$ & $137 \mathrm{~V} / \mathrm{m}$ & $137 \mathrm{~V} / \mathrm{m}$ \\
\hline $6 \mathrm{GHz}$ & Digital radio & $137 \mathrm{~V} / \mathrm{m}$ & $137 \mathrm{~V} / \mathrm{m}$ & $137 \mathrm{~V} / \mathrm{m}$ \\
\hline $20 \mathrm{GHz}$ & $\begin{array}{l}\text { Satellite } \\
\text { transmission }\end{array}$ & $137 \mathrm{~V} / \mathrm{m}$ & $137 \mathrm{~V} / \mathrm{m}$ & $137 \mathrm{~V} / \mathrm{m}$ \\
\hline
\end{tabular}

Table 1. Exposure limits in comparison

\section{Exposure systems}

Progress in understanding biological effects of non-ionizing electromagnetic radiation is closely related to measurement capability.

To be able to measure any effect of electromagnetic radiation it is necessary to have appropriate exposure system. During last ten years more various exposure systems where developed for research of biological effects and this systems are from constantly adopting accoring needs. Most of them belong to one of the following basic design ideas: Transverzal Electromagnetic (TEM) cell, RF chambers, radial transmission lines (RTL), waveguides or Wire Patch Cells (WPC).

Well defined exposure conditions are essential to optain reproducible results ant they are an precondition for the repeatability of studies.

All enviromental requirements for the specific experiment must be strcly complied to it.

Field distribution should be homogenious, i.e., the deviation from homogenety should be as small as possible.

In qualitative comparison of five differend exposure sistems (Table 2.) Schoenberg et al. (2001) came to conclusion that best results were achived by wire patch cell and RF chambers for the exposure of cells in homogenous suspension in $60 \mathrm{~mm}$ Petri dishes and T-75 flasks. But none of discussed approaches enabled exposure with reasonable homogenity.

The decision which wxposure system is most appropriate for certan in vitro study depends on numerical and technical requirements. Therfore Schoenberg et al, recommend close cooperation of biological and engineering experts in designing any in vitro exposure setup. 


\begin{tabular}{|l|l|l|l|l|l|}
\hline & TEM Cell & $\begin{array}{l}\text { RF } \\
\text { Chamber }\end{array}$ & RTL & Waveguide & $\begin{array}{l}\text { Wire } \\
\text { Patch cell }\end{array}$ \\
\hline Frequency range & $<1 \mathrm{GHz}$ & $\begin{array}{l}\text { Up to } \\
\text { several } \\
\mathrm{GHz}\end{array}$ & $<3 \mathrm{GHz}$ & $0.7-2 \mathrm{GHz}$ & $0.7-2 \mathrm{GHz}$ \\
\hline $\begin{array}{l}\text { Number of } \\
\text { dishes }\end{array}$ & 2 & $>20$ & 20 & $4-10$ & $8(1)$ \\
\hline $\begin{array}{l}\text { Preferred } \\
\text { Polarization }\end{array}$ & $\mathrm{E}(2)$ & $\mathrm{k}(3)$ & $\mathrm{E}$ & $\mathrm{E}(2)$ & $\mathrm{E}$ \\
\hline Efficiency & Low & Medium & Medium & High & High \\
\hline $\begin{array}{l}\text { Power } \\
\text { requirements }\end{array}$ & High & High & Medium & Low & Low \\
\hline Inhomogeneity & Low & High & Medium & Medium & Medium \\
\hline Complexity & Low & High & Medium & Low & Low \\
\hline Size & Small & Large & Medium & Medium & Small \\
\hline System cost & High & High & Moderate & Moderate & Moderate \\
\hline $\begin{array}{l}\text { Environmental } \\
\text { control }\end{array}$ & Incubator & Self-built & Self-built & Incubator & Incubator \\
\hline $\begin{array}{l}\text { Electromagnetic } \\
\text { shielding }\end{array}$ & $\begin{array}{l}\text { Self- } \\
\text { contained }\end{array}$ & Self-built & Self-built & $\begin{array}{l}\text { Self- } \\
\text { contained }\end{array}$ & Self-build \\
\hline $\begin{array}{l}\text { Exposure control } \\
\text { Power } \\
\text { meter }\end{array}$ & $\begin{array}{l}\text { Power } \\
\text { meter }\end{array}$ & $\begin{array}{l}\text { Power } \\
\text { meter }\end{array}$ & $\begin{array}{l}\text { Power } \\
\text { meter }\end{array}$ & $\begin{array}{l}\text { Field } \\
\text { probe(4) }\end{array}$ \\
\hline
\end{tabular}

(1) $35 \mathrm{~mm}$ Petri dishes placed into $60 \mathrm{~mm}$ Petri dishes with same medium height.

(2) $\mathrm{k}$ and $\mathrm{H}$ polarizations lead to poor homogeneity and are not further considered

(3) E polarization leads to excessive power requirements and is not further considered

(4) Field probe must be used for control in resonating structures (Schoenborn et al, 2001)

Table 2. Qualitative comparison of the performance of five designs for the exposure of plated cells in $60 \mathrm{~mm}$ Petri dishes.

\subsection{Transverse electromagnetic (TEM) Cell}

A transverse electromagnetic (TEM) cells ware the most often used in bioelectromagnetic experiments, EMC investigations and other studies as a source of standard electromagnetic field. It was developed by Litovitz et al. [1993] and utilized by Penafiel et al. [1997] for the exposure of cells in T25 flasks at $835 \mathrm{MHz}-$

TEM cell is an exposure system that combines characteristics as : generation of uniform field or a homogeniuos plane wave, usable cell volume for placing samples, shielding from electromagnetic influence both from outside and inside, it operates

over a wide frequency band, generates a planewave, field strength can be computed from the radiofrequency (RF) power travelling the cell.

TEM sells can be made in various sizes to siut the experimental requirements. The width of the cell must be less then one-half the wavelenght at the highest operating frequency to prevent higher-order-mode or multimoding effects. They are in use for upper frequency limits of 50, 150, 300, 500, and 1000MHz. TEM cells used for frequencies in Giga-hertz area are called Giga-hertz transverse electromagnetic GTEM cells. 
Field strenghts which can be achived in TEM cells go from very low to extremely high values depending on the input power.

At higher frequencies the cells are compact, portable, simple to build, and can be used for broadband operation up to higher frequency limit. The major disadvantage of the TEM cell is the restriction on specimen size imposed by the cell dimensions, which is inversely proportional to the upper frequency limit (Donaldson et al, 1978)

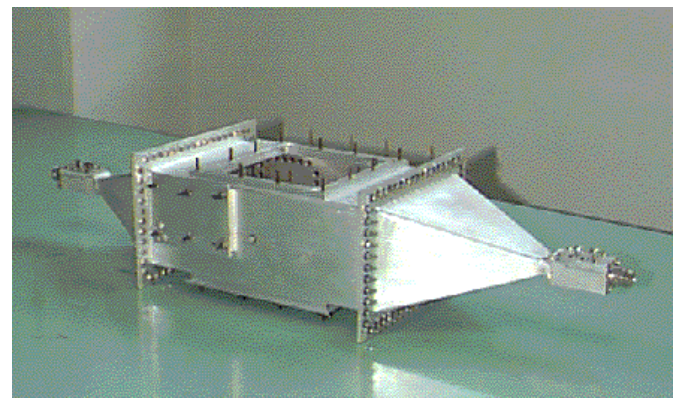

Fig. 1. Example of TEM cell.

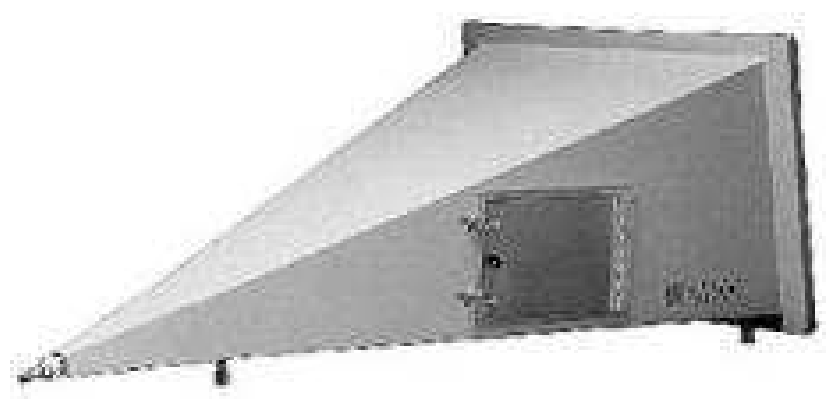

Fig. 2. Example of GTEM-cell.

\subsection{Wire Patch Cell}

A wire patch cell has been designed for exposing cell cultures during in vitro experiments studying possible effects of mobile radio telephone. It is based on the wire patch antenna which works at $900 \mathrm{MHz}$ with a highly homogeneous field inside the antenna cavity.

The designed cell structure is symmetric and provides a rather homogeneous field distribution in a large area around its centre. this small open device is easy to construct and fits into an incubator. AS the wire patch cell is a radiating element with the same radiating pattern as a dipole, and thus some absorbing materials are necessary around the system when used for in vitro experiments. Secondly, because of its narrow bandwidth, it is difficult to maintain its working frequency. ( Leval et al, 2000 )

The $900 \mathrm{MHz}$ WPC consist of two square plates (the ground plane and roof) of the same size $(15 \times 15 \mathrm{~cm} 2)$, spaced $2,9 \mathrm{~cm}$ apart using four metalic grounding contacts located at each corner of the cell. A coaxial cable is located at centre of the cell, with the ewternal conductor 
connected to the centre of the ground plane and the inner one passing trough the plate and then connecting to the roof.

Dimensions of radiating structure are related to the signal wavelenght and inversely proportional to the frequency (Ardoino et al, 2004).

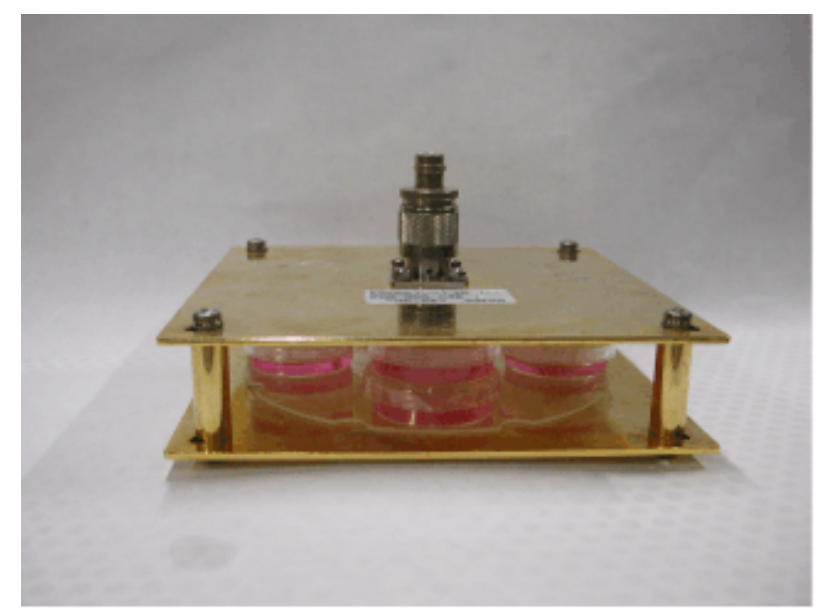

Fig. 3. Example of Wire Patch Cell containing four Petri dishes.

\section{GTEM cell and WPC modelling}

Before any constructing begins it is recommended to perform computer modelling of desired exposure system to investigate all needed requirements which are demanded from such systems, for example homogeneous field distribution, frequency range, etc .

As most of biological effects caused by high frequency electromagnetic radiation are thermal, temperature distribution and increase should be also taken into account in order to separate temperature rise because of exposure system itself and temperature rise due to electromagnetic field levels.

If temperature increase due tu exposure systems construction it self is noted it is necessary to consider implementation of some cooling system before performing electromagnetic exposure test. Othervise test results can be missinterpreted.

With QuickField software we have modelled GTEM cell and WPC. Our main goual was to determine possible temeperature increase in these two exposure systems.

QickField is a finite element analysis software package. Main application include computer simulations of electromagnetic fields for scientific and industrial purposes.

Modeled GTEM cell is $40 \mathrm{~cm}$ high and $60 \mathrm{~cm}$ wide. Antenna source is placed at $3 / 4$ of height. Modeled $1800 \mathrm{MHz}$ WPC has dimensions $20 \times 20 \mathrm{~cm}^{2}$ (model is 2 dimensional), with Petri dishes (radius $3.5 \mathrm{~cm}$ ) placed $5 \mathrm{~cm}$ from septum (centre). Dimensions of $1800 \mathrm{MHz}$ WPC were suggested by Ardoino et al., 2004 (Salovarda et al, 2007,2008). 


\subsection{Finite element method}

The Finite element method is used to solve complex, nonlinear problems in electromagnetism.[8][9] The first step in finite-element analysis is to divide the analyzed configuration into small homogeneous elements. The model contains information about the device geometry, material constants, excitations and boundary constraints. In each finite element, a linear variation of the field quantity is assumed. The corners of the elements are called nodes. The goal is to determine the field quantities at the nodes.

The Finite-element analysis technique solves the unknown field quantities by minimizing energy functional. The energy functional is an expression describing all the energy associated with the configuration being analyzed. For 3-dimensional, time-harmonic problems this functional may be represented as

$$
F=\int_{v} \frac{\mu|H|^{2}}{2}+\frac{\varepsilon|E|^{2}}{2}-\frac{J \cdot E}{2 j \omega} d v
$$

The first two terms in the integrand represent the energy stored in the magnetic and electric fields and the third term is the energy dissipated (or supplied) by the conduction currents.

By expressing $H$ in terms of $E$ and by setting the derivative of this functional with respect to $E$ equal to zero, an equation of the form $f(J, E)=0$ is obtained. A $k$ th order approximation of the function $f$ is then applied at each of the $N$ nodes and the boundary conditions are enforced, resulting in the system of equations.

$$
\left[\begin{array}{l}
J_{1} \\
J_{2} \\
\cdot \\
\cdot \\
J_{n}
\end{array}\right]=\left[\begin{array}{lll}
y_{11} & y_{12} & \cdots \\
y_{21} & y_{22} & \cdots \\
\cdots & \cdots \\
\cdots & \cdots \\
\cdots & y_{m n}
\end{array}\right]\left[\begin{array}{c}
E_{1} \\
E_{2} \\
\cdot \\
E_{n}
\end{array}\right]
$$

The values of $J$ on the left-hand side of this equation are the source terms. They represent the known excitations. The elements of the $Y$-matrix are functions of the analyzed problem geometry and the boundary constraints. Since each element only interacts with elements in its own neighborhood, the $Y$-matrix is sparse.

The terms of the vector on the right side represent the unknown electric field at each node. These values are obtained by solving the system of linear equations. In order to have a unique solution; it is necessary to constrain the field strength at all boundary nodes. (Malaric et al. 2005) 


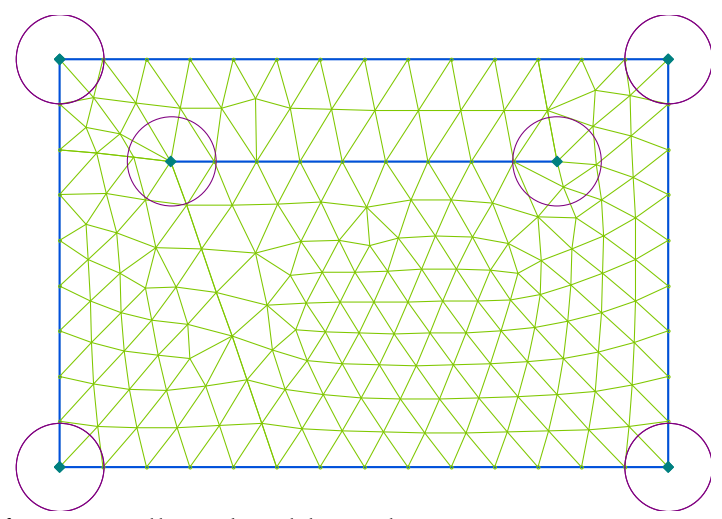

Fig. 4. FEM model of GTEM cell, QickField mesh

Applied mesh is shown in Figure 4 and the field values at the nodes have been calculated. In each finite element, a linear variation of the field quantity is assumed. The corners of the elements are called nodes. The goal is to find the electric field values at these nodes. Other parameters, such as the magnetic field, induced currents, and power loss can be obtained from the electric field values.

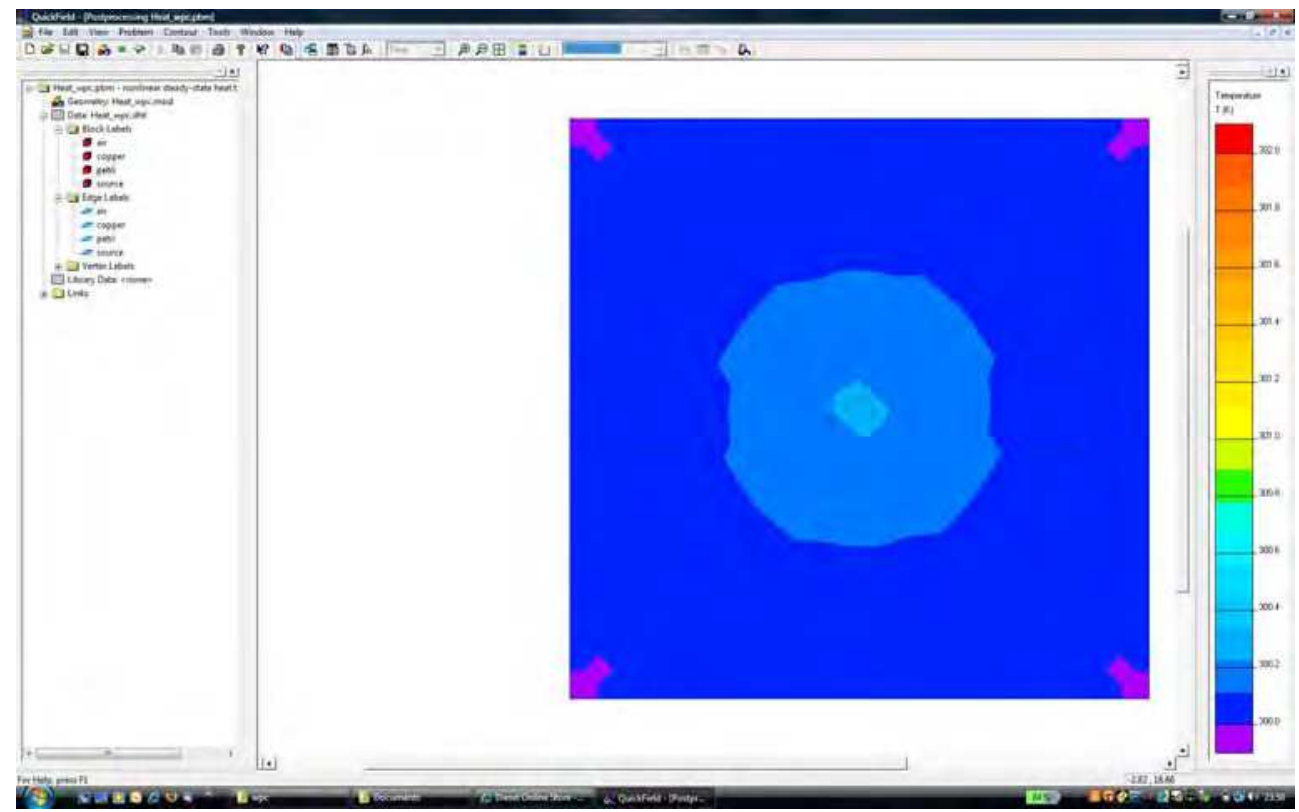

Fig. 5. Sample of QickField window showing final result. 


\subsection{Temperature distribution inside GTEM cell}

The characteristics of GTEM-cell are: $50 \Omega$ input impedance, inner conductor at $3 / 4$ height, inner height to width ratio equals $2 / 3$ and angle septum/bottom plate is $15^{\circ}$, with angle septum/top plate being $5^{\circ}$. The septum as well as coating is made of copper. The $\mathrm{N}$ type connector is placed at the end of the tapered section. If necessary, the connector can be replaced. The septum is supported by dielectric material. At the other end, there are the pyramidal absorbers $0.25 \mathrm{~m}$ long which are used for electromagnetic wave termination and two parallel $100 \Omega$, distributed resistive load for current termination. Figure 2 shows crosssession of the used GTEM-cell.

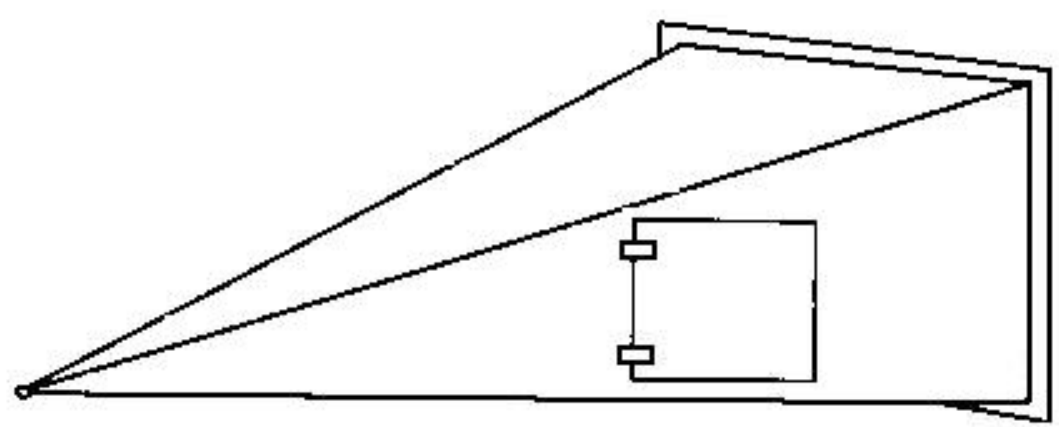

Fig. 5. GTEM-cell designed at Faculty of Electrical Engineering and Computing (FER)

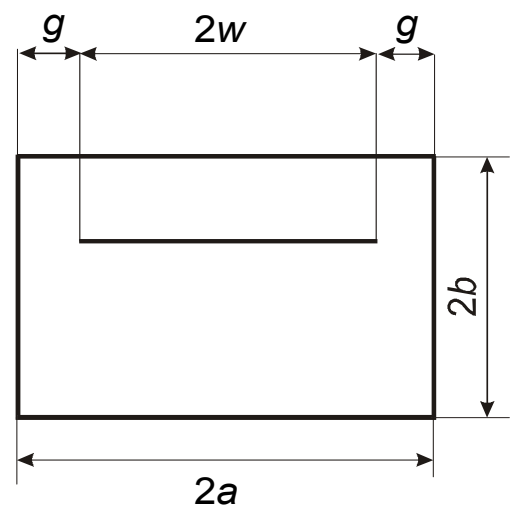

Fig. 6. Base of GTEM-cell designed at FER

By changing source values we wanted to se what is critical field value where temperatures are increased more than $1^{\circ} \mathrm{C}(1 \mathrm{~K})$ in the middle $15 \mathrm{~cm}$ below septum. Surrounding temperature in all cases was $300 \mathrm{~K}$. Fig. 3 and 5 show the result of numerical modeling analysis of E-strength and fig.4 and 6. results of temperature distribution in cell due to E field. Warmer colors on figures are higher values of E field or temperatures. 


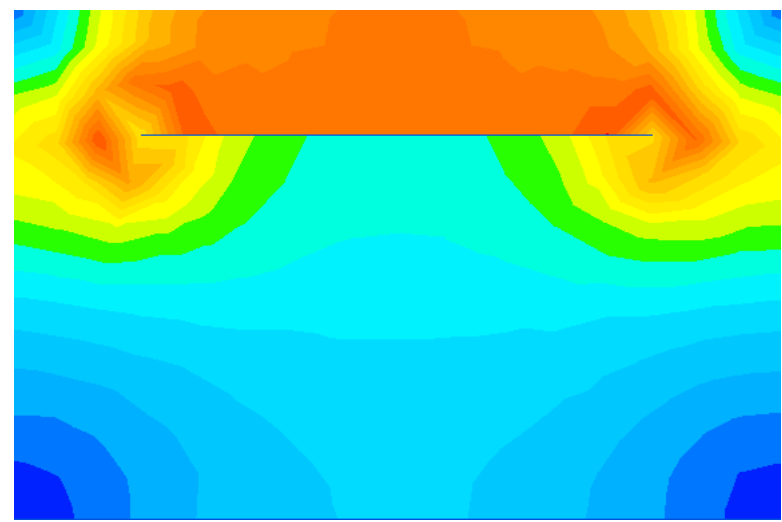

Fig. 7. E field distribution in of simulated GTEM. $E=3.28 \mathrm{~V} / \mathrm{m}$ in the middle $15 \mathrm{~cm}$ below septum.

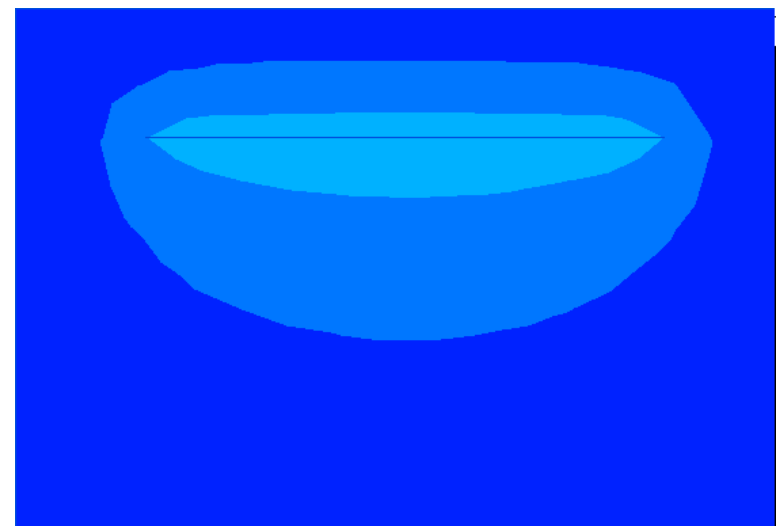

Fig. 8. Temperature distribution due to E field below the septum from fig.7. Temperature in the middle $15 \mathrm{~cm}$ below septum is $300.003 \mathrm{~K}(\mathrm{E}=3.28 \mathrm{~V} / \mathrm{m})$

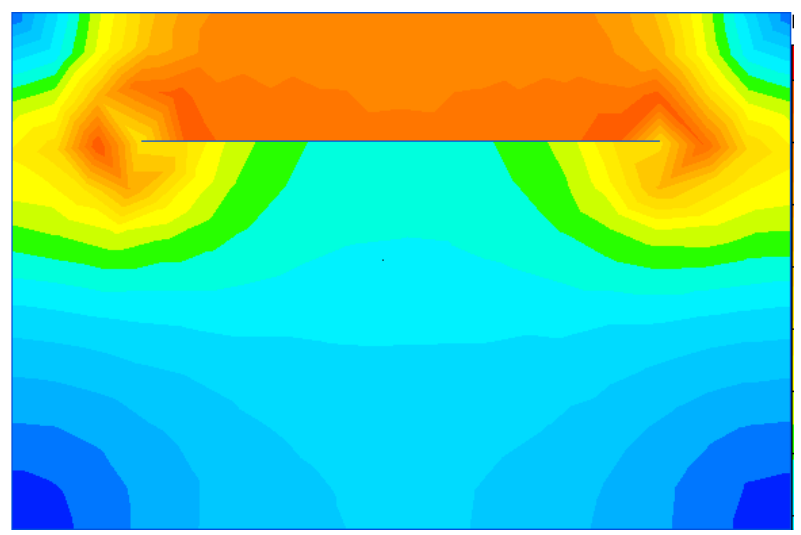

Fig. 9. E field distribution in of simulated GTEM. $E=23 \mathrm{~V} / \mathrm{m}$ in the middle $15 \mathrm{~cm}$ below septum. 


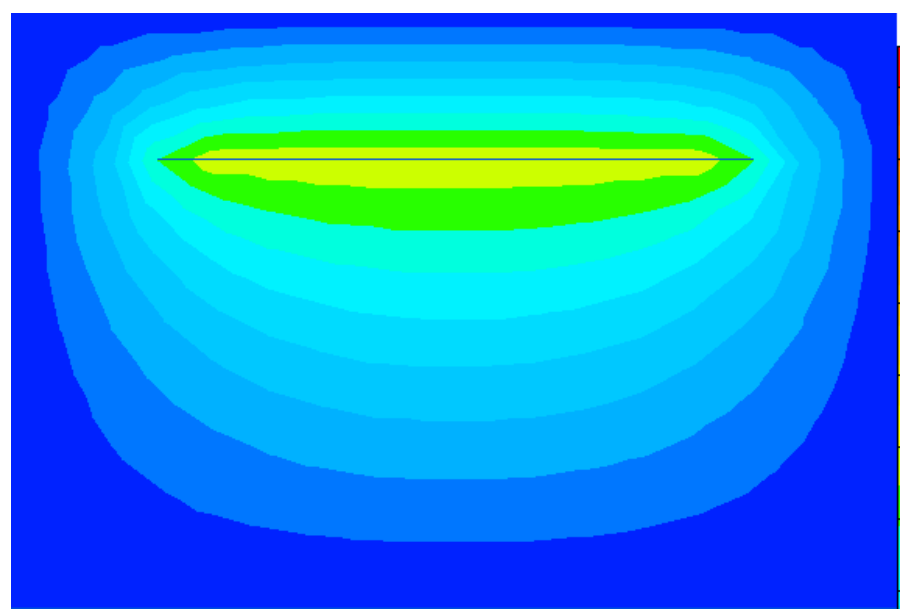

Fig. 10. Temperature distribution due to $\mathrm{E}$ field below the septum from fig.9. Temperature in the middle $15 \mathrm{~cm}$ below septum is $300.144 \mathrm{~K}(\mathrm{E}=23 \mathrm{~V} / \mathrm{m})$

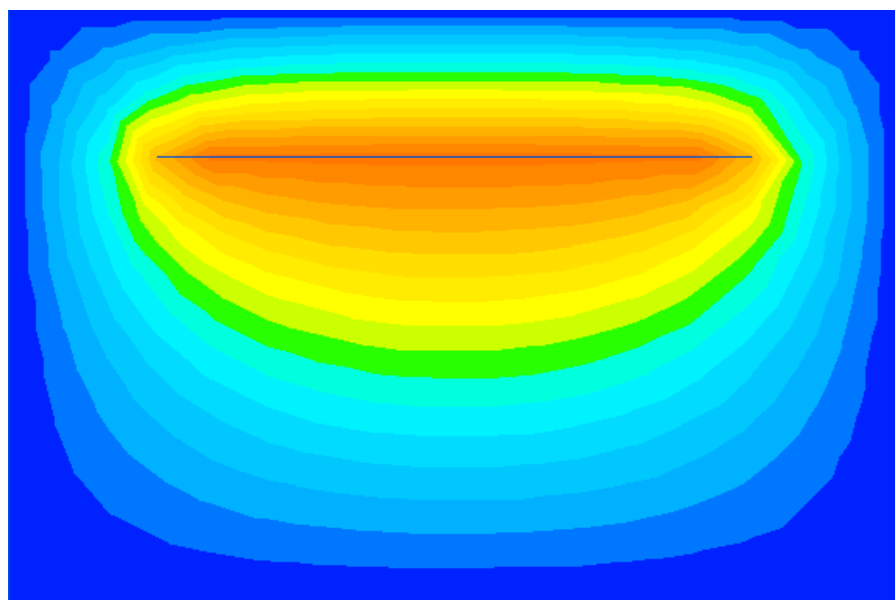

Fig. 11. Temperature in the middle $15 \mathrm{~cm}$ below septum is $301.161 \mathrm{~K}(\mathrm{E}=65.63 \mathrm{~V} / \mathrm{m})$.

\begin{tabular}{|c|c|c|c|}
\hline $\begin{array}{c}\text { Source Voltage } \\
(\mathbf{V})\end{array}$ & E strenght (V/m) & $\begin{array}{c}\text { Power density } \\
\left(\mathbf{m W} / \mathbf{c m}^{2}\right)\end{array}$ & $\begin{array}{c}\Delta \mathbf{T}\left(\mathbf{T}-\mathbf{T}^{\mathbf{0}}\right) \mathbf{K}, \\
\mathbf{T}_{\mathbf{0}}=\mathbf{3 0 0 K}\end{array}$ \\
\hline 1 & 3.28 & 0.00285376 & 0.003 \\
\hline 7 & 23 & 0.14032202 & 0.144 \\
\hline 20 & 65.63 & 1.14150507 & 1.161 \\
\hline
\end{tabular}

Table 3 . E field in the middle $15 \mathrm{~cm}$ below the septum

In case when E field $15 \mathrm{~cm}$ below septum is $23 \mathrm{~V} / \mathrm{m}$ (fig. 5,6,7), temperature on same place is $300.144 \mathrm{~K}$. Similar situation was measured in reference [10], when they observed 
influence of EMF on Lemna Minor growth in GTEM cell. Plants were exposed to field strength of $23 \mathrm{~V} / \mathrm{m}$ for 4 hours. The temperature of plants which were placed $15 \mathrm{~cm}$ below septum at the beginning and at the end of measurements varied no more than $\pm 0.1^{\circ} \mathrm{C}$. This measured temperature corresponds to our model in same environment (Tkalec et al, 2005).

\subsection{Temperature distribution inside WPC}

Performed were several tests with different power output level in order to see increase of temperature on places where petri dishes (samples) are. Starting temperature $\left(\mathrm{T}_{0}\right)$ in all cases was chosen to be $300 \mathrm{~K}$.

Warmer colors in figures below indicate higher values of E-field as well as of temperature.

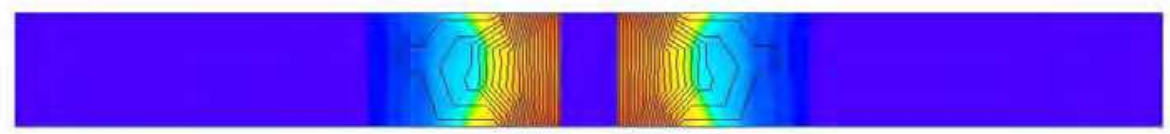

Fig. 12. Vertical E field distribution in side WPC for source $10 \mathrm{~V}$.

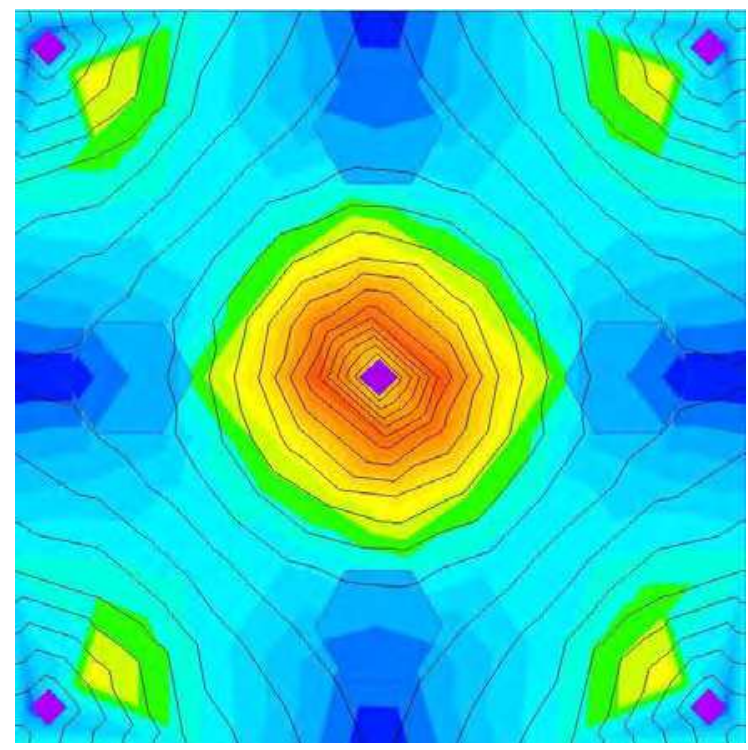

Fig. 13. Horizontal E field distribution in side WPC for source 10V. 


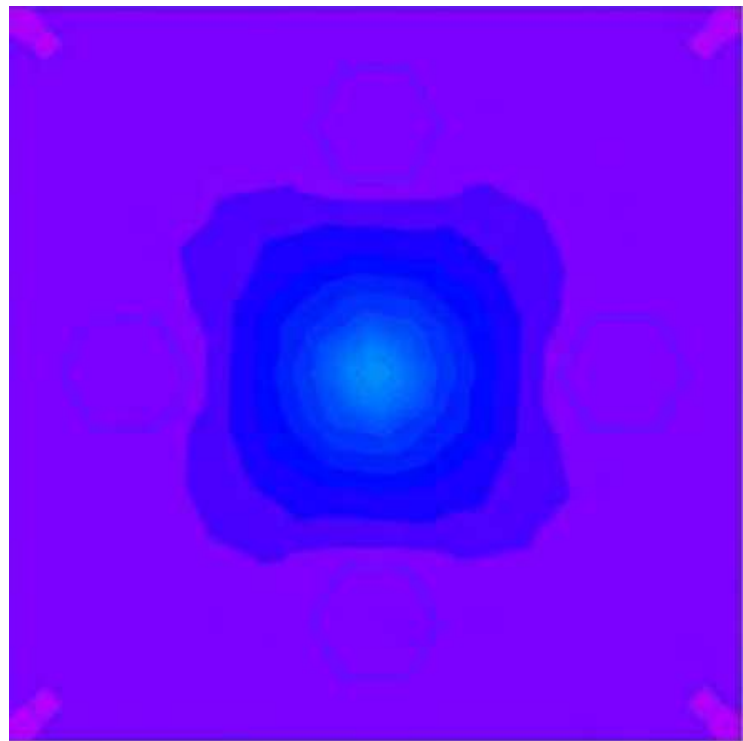

Fig.14. Temperature distribution for $2 \mathrm{~V}$ source. Temperature value in centre of WPC is $300.226 \mathrm{~K}($ E-field $=26.84 \mathrm{~V} / \mathrm{m})$. Temperature value $6.5 \mathrm{~cm}$ from septum $($ centre Petri dish $)=$ 300.006K $($ E-field $=4.4 \mathrm{~V} / \mathrm{m})$.

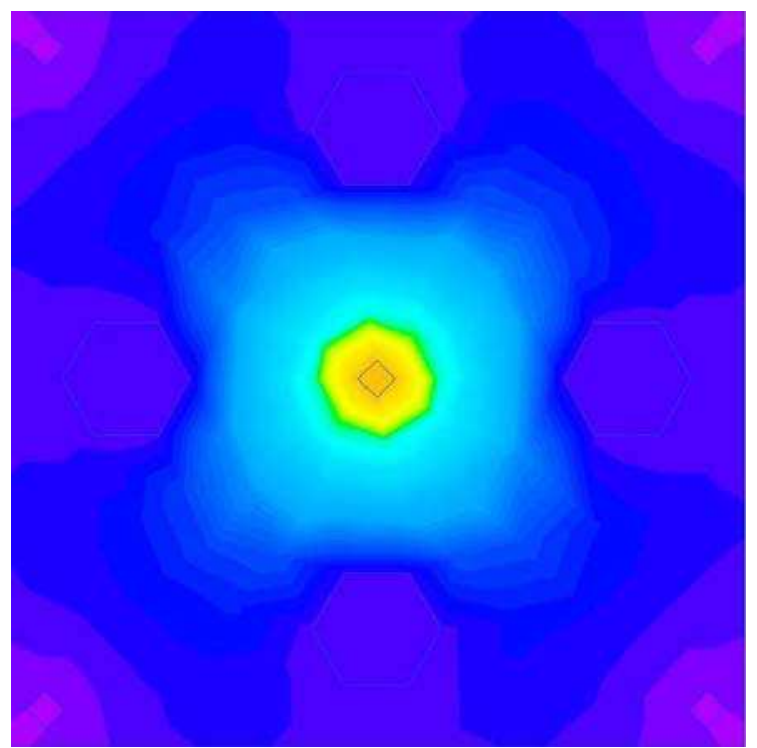

Fig. 15. Temperature distribution for $5 \mathrm{~V}$ source. Temperature value in centre of WPC is $301.140 \mathrm{~K}($ E-field $=67.11 \mathrm{~V} / \mathrm{m})$. Temperature value $6.5 \mathrm{~cm}$ from septum $($ centre Petri dish $)=$ 300.049K $($ E-field $=10.9 \mathrm{~V} / \mathrm{m})$. 
Fig. 17. Temperature distribution for $10 \mathrm{~V}$ source. Temperature value in centre of WPC $=$ $305.54 \mathrm{~K}$. Temperature value $6.5 \mathrm{~cm}$ from septum (centre Petri dish) $=300.195 \mathrm{~K}$.

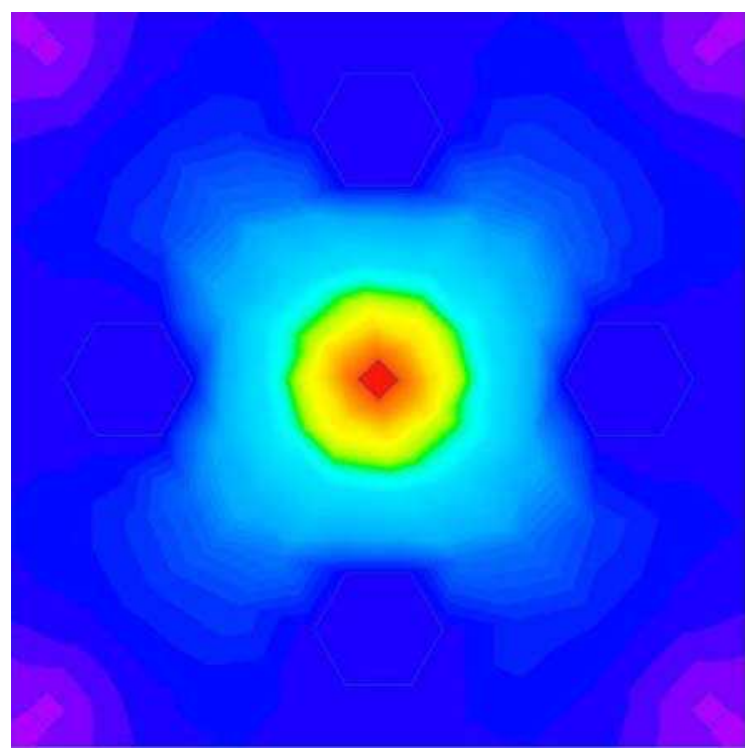

Fig. 18. Temperature distribution for $30 \mathrm{~V}$ source. Temperature value in centre of WPC = $334.82 \mathrm{~K}$. Temperature value $6.5 \mathrm{~cm}$ from septum (centre of Petri dish) $=301.52 \mathrm{~K}$. 


\begin{tabular}{|c|c|c|c|}
\hline $\begin{array}{c}\text { Source Voltage } \\
\text { (V) }\end{array}$ & $\begin{array}{l}\text { E strenght in the } \\
\text { middle of petri } \\
\text { dish, } 6.5 \mathrm{~cm} \text { from } \\
\text { septum }(\mathrm{V} / \mathrm{m})\end{array}$ & $\begin{array}{l}\text { Power density in } \\
\text { the middle of petri } \\
\text { dish, } 6.5 \mathrm{~cm} \text { from } \\
\text { septum, }\left(\mathrm{mW} / \mathrm{cm}^{2}\right)\end{array}$ & $\begin{array}{l}\Delta \mathrm{T}\left(\mathrm{T}-\mathrm{T}^{0}\right) \mathrm{K}, \\
\mathrm{T}_{0}=300 \mathrm{~K}\end{array}$ \\
\hline 1 & 2.2 & 0.0013 & 0.002 \\
\hline 2 & 4.4 & 0.0051 & 0.006 \\
\hline 5 & 10.9 & 0.0319 & 0.049 \\
\hline 10 & 21.9 & 0.1278 & 0.195 \\
\hline 20 & 43.9 & 0.5114 & 0.738 \\
\hline 30 & 65.8 & 1.1507 & 1.517 \\
\hline
\end{tabular}

Table 4. E-field and temperature increase in $6.5 \mathrm{~cm}$ from septum (centre of Petri dish).

\section{Conclusion}

By comparing WPC simulation results with simulation result performed on G-TEM cell (40 cm high and $60 \mathrm{~cm}$ wide, antenna source placed at $3 / 4$ of height) similarities are shown.

The low E field levels $(2 \mathrm{~V} / \mathrm{m}-11 \mathrm{~V} / \mathrm{m})$ should not cause any significant change of the temperature, but temperature rise for higher E-field levels should not be ignored $(65.8 \mathrm{~V} / \mathrm{m}$ $=\Delta \mathrm{T} 1.517 \mathrm{~K})$.

We see significant temperature increase close to septum (e.g. $65.8 \mathrm{~V} / \mathrm{m}=\Delta \mathrm{T} 34.82 \mathrm{~K}$ ). Therefore it is recomended to implement cooling system in order to avoide possible biological effects from heating rather then electromagnetic field itself. One exaple of cooling could be two water spiral-plate jackets placed on external faces of WPC. (Ardoino et al., 2004.) Next our step is to build WPC according gained knowlage. Then we will perform measurements of temperature rise depending on field strenghts both in GTEM cell andWPC.

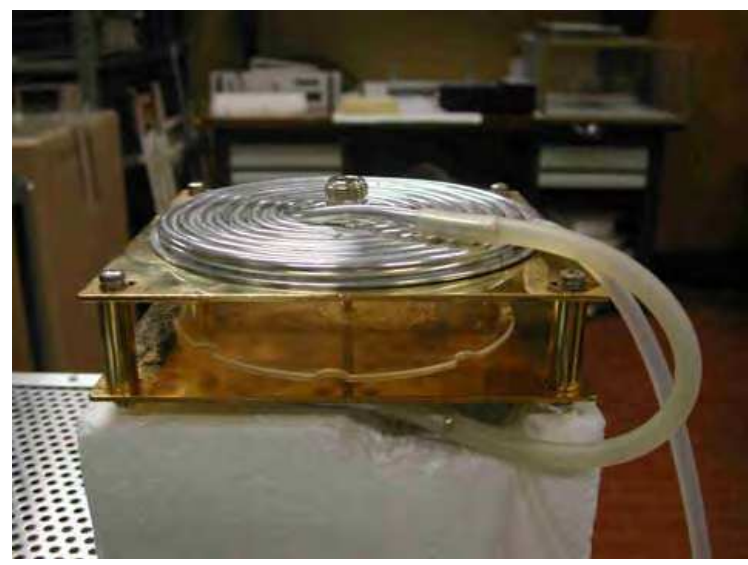

Fig. 19. Exaple of WPC with cooling system as two water spiral-plate jackets placed on external faces of WPC. 


\section{References}

Ardoino, L., Lopresto, V., Mancini, S., Pinto, R., Lovisolo, A. (2004). 1800 MHz In Vitro exposure device for experimental studies on the effects of mobile communication systems, Radiation Protection Dosimetry Vol. 112, No. 3, pp. 419-428 3.2

Leval, L., Leveque, P.H., Jecko, B., (2000). A new in vitro device for the mobile frequency $900 \mathrm{MHz}$, Bioelectromagnetics, No. 22, 255-263.

Malaric, K., Bartolic, J., Malaric, R. (2005). Immunity measurements of TV an FM/AM receiver in G-TEM-cell, Measurement, No. 38, pp. 219-229, Elsevier Ltd

Michelson, S.M.; Lin J.C. (1987). Biological Effects and Health Implications of Radiofrequency Radiation, Plenum Press, ISBN 0-306-41580-1, New York. 2. 3.

Salovarda, M., Malaric K., Malaric, R. (2007). Temeprature distribution inside GTEM-cell for biomedical experiments, Tehnicki glasnik, Casopis Veleucilista u Varazdinu,Vol.1, No.1-2; 16-19, ISSN 1846-6168

Salovarda, M., Malaric, K. (2008). Temperature Distribution Inside Wire Patch Cell, Proceedings of the 14th Conference on Microwave Techniques COMITE 2008, pp. 125128, ISBN 978-1-4244-2137-4, ,Prag Czechoslovakia Section IEEE, April 2008.

Schoenborn, F., Poković, K., Burkhardat, M., Kuster, N. (2001). Basis for Optimization of In Vitro Exposure Apertures for Health Hazard Evaluations of Mobile, Communications, No.22, 547 - 559 .

Tkalec, M., Malaric, K., Pavlek-Kozina, B. (2005). Influence of 400, 900, and $1900 \mathrm{MHz}$, Electromagnetic Fields on Lemma minor Growth and Peroxidise Activity. Bioelectromagnetics, No.26, 185-193. 


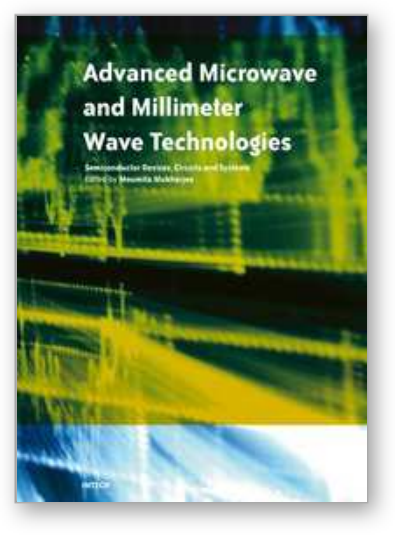

\section{Advanced Microwave and Millimeter Wave Technologies Semiconductor Devices Circuits and Systems}

Edited by Moumita Mukherjee

ISBN 978-953-307-031-5

Hard cover, 642 pages

Publisher InTech

Published online 01, March, 2010

Published in print edition March, 2010

This book is planned to publish with an objective to provide a state-of-the-art reference book in the areas of advanced microwave, MM-Wave and $\mathrm{THz}$ devices, antennas and systemtechnologies for microwave communication engineers, Scientists and post-graduate students of electrical and electronics engineering, applied physicists. This reference book is a collection of 30 Chapters characterized in 3 parts: Advanced Microwave and MM-wave devices, integrated microwave and MM-wave circuits and Antennas and advanced microwave computer techniques, focusing on simulation, theories and applications. This book provides a comprehensive overview of the components and devices used in microwave and MM-Wave circuits, including microwave transmission lines, resonators, filters, ferrite devices, solid state devices, transistor oscillators and amplifiers, directional couplers, microstripeline components, microwave detectors, mixers, converters and harmonic generators, and microwave solid-state switches, phase shifters and attenuators. Several applications area also discusses here, like consumer, industrial, biomedical, and chemical applications of microwave technology. It also covers microwave instrumentation and measurement, thermodynamics, and applications in navigation and radio communication.

\section{How to reference}

In order to correctly reference this scholarly work, feel free to copy and paste the following:

Marija Salovarda Lozo and Kresimir Malaric (2010). Use of GTEM-Cell and Wire Patch Cell in Calculating Thermal and Non-Thermal Biological Effects of Electromagnetic Fields, Advanced Microwave and Millimeter Wave Technologies Semiconductor Devices Circuits and Systems, Moumita Mukherjee (Ed.), ISBN: 978-953307-031-5, InTech, Available from: http://www.intechopen.com/books/advanced-microwave-and-millimeterwave-technologies-semiconductor-devices-circuits-and-systems/use-of-gtem-cell-and-wire-patch-cell-incalculating-thermal-and-non-thermal-biological-effects-of-el

\section{INTECH}

open science | open minds

\section{InTech Europe}

University Campus STeP Ri

Slavka Krautzeka 83/A

51000 Rijeka, Croatia

Phone: +385 (51) 770447

Fax: +385 (51) 686166

\section{InTech China}

Unit 405, Office Block, Hotel Equatorial Shanghai

No.65, Yan An Road (West), Shanghai, 200040, China 中国上海市延安西路65号上海国际贵都大饭店办公楼405单元

Phone: +86-21-62489820

Fax: +86-21-62489821 
www.intechopen.com 
(C) 2010 The Author(s). Licensee IntechOpen. This chapter is distributed under the terms of the Creative Commons Attribution-NonCommercialShareAlike-3.0 License, which permits use, distribution and reproduction for non-commercial purposes, provided the original is properly cited and derivative works building on this content are distributed under the same license. 